\title{
Pembuatan Masker Kain untuk Menangkal Penyebaran Covid-19 di Desa Kemuning Lor Kecamatan Arjasa Kabupaten Jember
}

\author{
Making a Fabric Masker to Prevent the Spread of Covid-19 in Kemuning Lor Village Arjasa \\ Sub District Jember Regency
}

\author{
Naning Retnowati ${ }^{1 *}$, R. Alamsyah Sutantio ${ }^{1}$, Alwan Abdurahman ${ }^{1}$ \\ ${ }^{1}$ Jurusan Manajemen Agribisnis, Politeknik Negeri Jember \\ *naning_retnowati@polije.ac.id
}

\begin{abstract}
ABSTRAK
Penyakit Coronavirus (COVID-19) adalah penyakit menular yang disebabkan oleh virus Severe Acute Respiratory Syndrome Coronavirus-2 (SARS-CoV2). Masker wajah tergolong dalam APD yang dapat melindungi manusia dari serangan Virus COVID-19. Masker untuk melindungi debu atau partikel yang masuk ke dalam pernafasan, juga dapat terbuat dari kain dengan ukuran tertentu. Bu Busani adalah salah seorang penjahit baju rumahan berkeinginan untuk membuat masker kain agar dapat memenuhi kebutuhan masyarakat terhadap masker kain. Permasalahan mitra dikarenakan : masih rendahnya kualitas dan kapasitas produksi mitra karena kurangnya bahan dan alat (mesin jahit) yang digunakan dalam pembuatan masker masih bersifat manual, minimnya informasi mitra tentang ide cara mendesain masker yang inovatif dan menarik serta sesuai dengan keinginan dan kebutuhan pelanggannya, minimnya informasi yang dimiliki mitra tentang cara pengelolaan usaha jahit baju yang baik sehingga keuntungan yang diperoleh menjadi tidak maksimal, minimnya informasi yang dimiliki mitra tentang cara pemasaran produk yang tepat. Pemberian bantuan alat dan mesin produksi kepada mitra diharapkan akan dapat meningkatkan efektifitas dan efisiensi proses produksi usaha jahit masker. Kegiatan pelatihan berupa pemberian materi bidang manajemen dan pemasaran diharapkan dapat memperbaiki kemampuan manajerial usaha mitra, dapat memperluas daerah pemasaran serta menemukan strategi tepat dalam memasarkan produk maskernya kepada konsumen. Melalui pelatihan desain masker diharapkan mitra akan dapat membuat masker yang menarik minat konsumen.
\end{abstract}

Kata kunci — masker, pelatihan, usaha jahit baju

\begin{abstract}
Coronavirus disease (COVID-19) is a contagious disease caused by the Severe Acute Respiratory Syndrome Coronavirus-2 (SARS-CoV2) virus. Face masks are classified as PPE that can protect humans from the COVID19 Virus attack. Masks to protect dust or particles that enter the breath, can also be made of cloth of a certain size. Bu Busani is a tailor at home with a desire to make cloth masks in order to meet the people's needs for cloth masks. Partners' problems are the lack of materials and tools (sewing machines) used in making masks, lack of partner information about how to design attractive masks, how to manage a business and how to market products. Providing assistance with production tools and machines to partners can increase the effectiveness and efficiency of the mask sewing business production process. Through mask design training, it is hoped that partners will be able to make masks that attract consumers. Training activities in the form of providing material in the field of management and marketing are expected to improve the managerial abilities of partner businesses, expand the marketing area and find the right strategy in marketing mask products to consumers.
\end{abstract}

Keywords - masks, training, clothes sewing business 


\section{Pendahuluan}

Penyakit coronavirus (COVID-19) adalah penyakit menular yang disebabkan oleh virus Severe Acute Respiratory Syndrome Coronavirus-2 (SARS-CoV2). Penyakit ini ditularkan melalui manusia ke manusia di mana sebagian besar orang yang terinfeksi (COVID19) akan mengalami penyakit pernapasan ringan hingga sedang dan sembuh tanpa memerlukan perawatan khusus. Pada penderita usia lanjut dan memiliki masalah kesehatan lain seperti penyakit kardiovaskular, diabetes, penyakit pernapasan kronis, dan kanker, dapat memperberat penyakit tersebut.

Kasus COVID-19 di Indonesia yang meningkat setiap hari mengakibatkan harga semua jenis APD melambung tinggi dan langka akibat pasokan yang terhambat, termasuk diantaranya harga masker wajah (medis). Alat pelindung diri (APD) adalah perangkat alat yang dirancang sebagai penghalang terhadap penetrasi zat, partikel padat, cair, atau udara untuk melindungi pemakainya dari cedera atau penyebaran infeksi atau penyakit. Apabila digunakan dengan benar, APD bertindak sebagai penghalang antara bahan infeksius (misalnya virus dan bakteri) dan kulit, mulut, hidung, atau mata (selaput lendir) tenaga kesehatan dan pasien. Penghalang memiliki potensi untuk memblokir penularan kontaminan dari darah, cairan tubuh, atau sekresi pernapasan. Selain itu praktik pengendalian infeksi lainnya seperti mencuci tangan, menggunakan pembersih tangan berbasis alkohol, dan menutupi hidung dan mulut saat batuk dan bersin dengan lengan atas bagian dalam atau tisu, dapat meminimalkan penyebaran infeksi dari satu orang ke orang lain. Penggunaan APD yang efektif mencakup pemindahan dan atau pembuangan APD yang terkontaminasi dengan benar untuk mencegah terpaparnya pemakai dan orang lain terhadap bahan infeksius.[1]

Alat pelindung pernapasan atau masker merupakan alat yang di-gunakan untuk melindungi mulut dan hidung dengan bahan yang dapat menyaring masuknya debu atau uap [2]. Masker wajah tergolong dalam APD yang dapat melindungi manusia dari serangan Virus COVID-19. Penggunaan masker di masa pandemi Covid-19 ini menjadi hal yang sangat penting untuk memproteksi diri dan juga orang lain dari risiko penularan virus ini. Sebagaimana diketahui bahwa sebagian besar penularan Covid-19 adalah melalui droplets, masker dapat menjadi barrier bagi tetesan baik yang datang dari dalam diri maupun dari orang lain. Masker untuk melindungi debu atau partikel yang masuk ke dalam pernafasan, juga dapat terbuat dari kain dengan ukuran tertentu [3]. Masker kain adalah masker yang berbentuk seperti masker sekali pakai namun dibuat menggunakan material kain yang lebih tebal dari masker sekali pakai seperti katun atau kaos.

Kabupaten Jember merupakan kota kabupaten dan terletak di Provinsi Jawa Timur, berjarak sekitar $200 \mathrm{~km}$ dari kota Surabaya ke arah timur. Kabupaten ini terdiri dari 31 Kecamatan dengan jumlah desa sebanyak 248 Desa. Kepadatan penduduk di Kabupaten Jember berdasarkan Hasil Proyeksi Penduduk pada akhir tahun 2019 jumlah penduduk di Kabupaten Jember adalah 2.450.668 jiwa dengan pertumbuhan penduduk $0,38 \%$ per tahun [4]. Kondisi jumlah penduduk dengan tingkat kepadatan penduduknya yang cukup tinggi, maka masyarakat di Kabupaten Jember sangat berisiko terpapar Virus Covid-19.

Upaya yang dilakukan oleh Pemkab Jember untuk mencegah penyebaran Virus COVID-19 maka Bupati Faida pada tanggal 4 April 2020 menyiapkan 2 juta masker (non medis) berbahan kain untuk dibagikan secara gratis kepada penduduk Jember. Kini masker tersebut sedang dikerjakan oleh sejumlah penjahit lokal [5]. Diharapkan masyarakat selalu tertib dan disiplin untuk mengenakan masker saat keluar rumah.

Akan tetapi jumlah masker masih sangat terbatas jumlahnya dikarenakan tidak semua penjahit rumahan di Kabupaten Jember diberdayakan dalam pembuatan masker berbahan kain (non medis) ini dikarenakan lokasi usaha mereka yang terpencil karena jauh dari perkotaan dan kurang strategis. Selain itu banyak wirausaha di bidang jahit baju yang belum terdaftar pada Dinas Industri.

Pada Dusun Kopang Krajan Desa Kemuning Lor Kecamatan Arjasa Kabupaten Jember terdapat seorang penjahit baju rumahan bernama Bu Busani. Bu Busani tergerak untuk menjadi berwirausaha sebagai penjahit baju sejak 
2015 dikarenakan ingin menambah penghasilan keluarga. Bu Busani hanya memiliki satu mesin jahit yang sederhana yakni fungsi tunggal tanpa adaptor (manual) sehingga cukup berat dirasakan mitra saat mengoperasikan mesin jahit ini. Mitra sangat membutuhkan bantuan berupa mesin jahit portable yang dilengkapi dengan adaptor untuk memudahkan dalam menjahit baju dan masker.

Usaha jahit baju yang dilakukan selama 5 tahun ini belum menunjukkan perkembangan yang berarti dikarenakan mitra masih belum memahami bagaimana cara mengelola usaha yang baik. Selain itu ditambah lagi di tengah pandemi Corona ini, penghasilan $\mathrm{Bu}$ Busani sebagai penjahit baju rumahan menurun drastis. Selain itu banyaknya toko online yang menawarkan pakaian dengan desain yang menarik dan harga ekonomis menjadi pilihan menarik bagi masyarakat, sehingga mereka enggan untuk menjahitkan baju pada penjahit.

Di tengah memburuknya kondisi akibat wabah Corona, terdorong keinginan $\mathrm{Bu}$ Busani agar dapat memenuhi kebutuhan masyarakat terhadap masker kain, maka dari itu mitra berinisiatif untuk membuat beberapa masker kain dengan menggunakan kain perca sisa bahan kain. Akan tetapi tidak banyak orang yang tertarik untuk membeli masker kain buatan Bu Busani dikarenakan desainnya yang kurang menarik dan bahan yang kurang baik kualitasnya. Mitra sangat membutuhkan bantuan bahan dalam pembuatan masker kain. Selain itu pada aspek manajemen mitra membutuhkan pembinaan berupa pelatihan bidang manajemen usaha jahit masker kain agar dapat mencapai keuntungan yang maksimal dan manajemen pemasaran sehingga dapat menjangkau daerah pemasaran secara lebih luas bila kelak jumlah pelanggannya bertambah.

\section{Target dan Luaran}

\subsection{Target}

Beberapa target dalam kegiatan Pengabdian Kepada Masyarakat ini yaitu:

a. Meningkatkan pengetahuan dan motivasi mitra tentang pembuatan produk masker yang inovatif, berkualitas baik dan kreatif;

b. Meningkatkan kemampuan manajemen usaha sehingga senantiasa dapat menghasilkan keuntungan (profit); c. Meningkatkan kemampuan manajemen pemasaran sehingga area wilayah pemasaran mitra semakin luas (melalui media online);

d. Pelaksanaan Seminar Nasional Pengabdian Kepada Masyarakat;

e. Diterbitkannya artikel ilmiah berupa Prosiding Pengabdian Masyarakat (published).

f. Publikasi di media massa (cetak, elektronik).

g. Disusunnya artikel ilmiah berupa Jurnal JDINAMIKA (accepted)

\subsection{Luaran}

Luaran dari kegiatan Pengabdian Kepada Masyarakat ini adalah:

a. Peningkatan pengetahuan dan kemampuan produksi mitra tentang cara membuat produk (masker kain) yang berkualitas baik, inovatif, menarik dan sesuai dengan keinginan dan kebutuhan pelanggan.

b. Peningkatan motivasi dan kemampuan mitra dalam berwirausaha dan agar senantiasa menambah pengetahuannya tentang cara mendesain produk masker yang inovatif, dan menarik serta sesuai dengan keinginan pelanggannya.

c. Peningkatan pendapatan mitra

d. Peningkatan kemampuan manajemen usaha dan pemasaran mitra menjadi lebih baik lagi.

e. Berperan serta menyukseskan program pemerintah di bidang kesehatan yaitu mencegah penyebaran Virus COVID-19 dengan cara membantu penyediaan masker kain (non medis) bagi masyarakat.

\section{Metodologi}

3.1. Rencana Kegiatan dan Metode yang Ditawarkan

Adapun metode pendekatan yang ditawarkan adalah sebagai berikut :

\subsubsection{Studi pustaka dan observasi lapang}

a. Studi pustaka yang dibutuhkan untuk membuat desain pola masker non medis yang menarik dan trendy, adalah:

- Gambar desain aneka jenis masker yang inovatif, menarik dan kekinian;

- Pengetahuan tentang macam bahan kain yang dapat digunakan untuk membuat 
masker yang berkualitas baik dan jumlah lapisan bahan kain yang efektif untuk digunakan sebagai APD (Alat Pelindung Diri).

b. Observasi lapang yang dilakukan adalah:

- Mengamati kualitas produk jahitan yang dihasilkan mitra;

- Mengamati peralatan produksi (menjahit) yang digunakan mitra;

- Mengamati pengelolaan usaha yang dijalankan mitra;

- Mengamati kondisi pemasaran yang dilakukan mitra.

\subsubsection{Prosedur Kerja}

Prosedur kerja yang diterapkan pada kegiatan ini adalah sebagai berikut:

a. Persiapan;

b. Studi pustaka

Studi pustaka merupakan tahap paling awal. Pencarian literatur karya ilmiah, jurnal, dan data-data pendukung terkait apa yang akan digunakan dalam kegiatan Pengabdian Kepada Masyarakat ini.

c. Survei lapang

Tahapan ini meliputi pengumpulan data dan informasi di lapangan yang diperlukan untuk pengerjaan dari hasil tahap pertama. Tahap ini meliputi metode wawancara dan observasi.

d. Pengumpulan dan pengolahan data awal

e. Penyusunan kebutuhan alat menjahit dan pelatihan tentang mendesain produk agar lebih menarik minat pelanggan, pelatihan bidang manajemen usaha dan pemasaran;

f. Pembelian bahan, alat dan mesin jahit yang meliputi mesin jahit portable, penggaris jahit polaris untuk pola jahit, kain katun jepang dengan aneka motif, sewing kit;

g. Pelatihan tentang cara mendesain produk masker kain (non medis), manajemen usaha dan pemasaran;

h. Monitoring dan evaluasi;

i. Pembuatan laporan.

\subsection{Partisipasi Mitra Dalam Pelaksanaan Program}

Partisipasi mitra dalam pelaksanaan program yakni membantu tim pelaksana pengabdian menyediakan lokasi pelatihan dan setelah pelaksanaan kegiatan pengabdian adalah membantu tim pelaksana turut menyampaikan informasi penting kepada masyarakat (penduduk sekitar lokasi mitra) tentang cara pembuatan produk masker kain yang inovatif dan kreatif dengan beraneka bahan dan model/desain, cara pengelolaan suatu usaha secara lebih baik agar dapat menghasilkan keuntungan/profit bagi wirausaha lain di daerah sekitar rumah mitra, dan cara pemasaran produk melalui media online untuk menjangkau pasar (pelanggan) yang lebih luas lagi.

\subsection{Langkah Evaluasi Pelaksanaan dan Keberlanjutan Program}

Langkah evaluasi pelaksanaan program dan keberlanjutan program di lapangan setelah kegiatan pengabdian selesai dilaksanakan :

a. Melakukan monitoring dan evaluasi pada mitra yang dilaksanakan setelah kegiatan pelatihan untuk mengetahui kondisi mitra : 1) apakah mitra mengalami kendala dalam membuat produk masker kain yang berkualitas baik, inovatif dan trendy; 2) apakah mitra dapat mengelola usaha dan memasarkan produknya dengan cara yang lebih baik dan apakah program pelatihan telah berjalan sesuai harapan.

b. Melakukan monitoring dan evaluasi pada mitra sebagai keberlanjutan program untuk mengetahui kondisi mitra : 1) apakah usaha mitra telah berkembang, 2) apakah mitra masih mengalami kendala dalam pembuatan produk masker yang, 3) apakah mitra masih mengalami kendala dalam proses pemasaran produknya. Tim pelaksana pengabdian juga akan berusaha untuk membantu permasalahan mitra walaupun kegiatan pengabdian telah berakhir.

\section{Pembahasan}

\subsection{Hasil}

Hasil yang telah dicapai dalam kegiatan ini adalah:

a. Kegiatan survei dan observasi mitra, Kegiatan ini berupa kunjungan ke rumah mitra untuk mengetahui kebutuhan para mitra dalam 
pembuatan masker. Kegiatan ini dilaksanakan tanggal 02 Agustus 2020.

b. Pembelian peralatan menjahit dan bahan kain dilakukan dari tanggal 01 sampai dengan 03 September 2020.

c. Merancang banner untuk pelaksanaan Pelatihan dilakukan tanggal 10 September 2020. Setelah rancangan banner selesai dibuat selanjutnya langsung dilakukan pemesanan ke percetakan.

d. Kegiatan serah terima alat dan mesin jahit portable dilakukan pada tanggal 13 September 2020.

e. Pelatihan pembuatan masker (cara kreatif dan inovatif), manajemen usaha dan pemasaran dilakukan pada tanggal dilakukan pada tanggal 13 September 2020.

f. Kegiatan pendampingan mitra dilakukan untuk mengetahui apakah mitra mengalami kendala dalam membuat masker kain sesuai keinginan dan kebutuhan konsumen. Pendampingan mitra dilakukan dalam hal pembuatan masker yang menarik, pendampingan manajemen usaha dan pemasaran. Pendampingan dilakukan pada tanggal 4, 11, dan 18 Oktober 2020.

g. Kegiatan monitoring dan evaluasi pada mitra dilakukan pada tanggal 25 Oktober 2020 untuk memastikan apakah mitra telah mampu mengembangkan usaha menjahitnya dan senantiasa menerapkan sisi inovatif dalam membuat masker sesuai keinginan dan kebutuhan konsumen.

\subsection{Pembahasan}

Kegiatan (utama) pengabdian masyarakat yang telah dilakukan oleh tim pelaksana kegiatan pengabdian meliputi : 1) pemberian fasilitas produksi (bahan dan alat produksi masker kain); 2) pelatihan kreativitas dan inovasi dalam pembuatan masker kain serta pelatihan manajemen usaha dan manajemen pemasaran, 3) pendampingan pada mitra, 4) monitoring dan evaluasi pada mitra.

Pemberian fasilitas produksi berupa peralatan jahit, mesin jahit portable dan bahan kepada mitra dilakukan untuk membantu dan memudahkan mitra dalam proses produksi/pembuatan masker kain sehingga diharapkan mitra dapat membuat masker kain dengan desain yang menarik dan kreatif sesuai dengan yang keinginan dan kebutuhan konsumen.

Pelatihan pembuatan masker kain ditujukan agar mitra memiliki daya kreativitas dan daya inovasi. Dalam pelatihan kreativitas mitra diberikan gambaran mengenai cara-cara menciptakan ide-ide baru mendesain masker kain dan tentang bagaimana menemukan cara baru dalam menyikapi masalah dan memanfaatkan peluang bisnis di bidang pembuatan dan menghias masker kain. Sedangkan dalam pelatihan inovasi mitra dilatih untuk dapat menerapkan gagasan-gagasan baru khususnya dalam mendesain masker kain yang sesuai dengan keinginan dan kebutuhan konsumen.

Pelatihan manajemen usaha berisi materi tentang bagaimana cara mengelola usaha agar tetap eksis di tengah persaingan/kompetisi yang semakin sulit. Pelatihan manajemen pemasaran berisi materi tentang cara memasarkan produk masker kain agar dapat laku di pasaran.

Kegiatan pelatihan tentang cara membuat masker, pelatihan manajemen usaha dan manajemen pemasaran yang diberikan kepada peserta berjalan dengan lancar dan sukses. Hal ini ditunjukkan dengan antusiasme para peserta pelatihan saat mengikuti kegiatan. Pemahaman peserta pelatihan tentang manajemen usaha, pemasaran dan cara membuat masker (yang menarik) juga semakin meningkat dengan diadakannya kegiatan ini, terbukti dari kemampuan peserta saat menjawab pertanyaan yang diberikan pemateri.

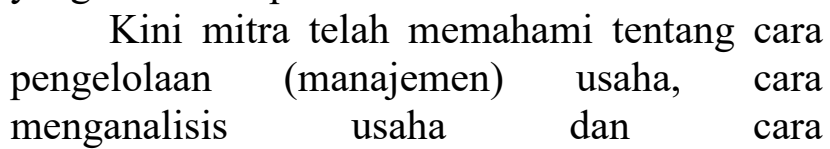
menghitung/menentukan keuntungan usaha. Mitra juga lebih memahami tentang cara memasarkan produk maskernya dan bagaimana cara mempromosikan produknya pada konsumen berupa cara penyampaian yang baik agar menarik minat masyarakat untuk membeli produk maskernya. Produk masker yang dijual $\mathrm{Bu}$ Busani biasanya dijual dengan cara menitipkan pada toko-toko di sekitar dan juga dijual pada para tetangga di sekitar rumah mitra.

Pendampingan pada mitra ditujukan agar mitra dapat menerapkan/mengimplementasikan hasil dari pelatihan dengan baik dan untuk mengetahui apakah mitra masih mengalami kendala dalam membuat masker kain dengan 
desain yang menarik dan sesuai dengan keinginan dan kebutuhan konsumen, cara mengelola usaha yang baik dan pemasaran produk.

Kegiatan monitoring dan evaluasi pada mitra dilakukan untuk memastikan apakah mitra telah mampu mengembangkan usaha menjahitnya, memperluas daerah pemasaran produk maskernya dan senantiasa menerapkan unsur kreativitas dalam membuat masker sesuai keinginan, harapan dan kebutuhan konsumen.

Beberapa dokumentasi dari kegiatan yang telah kami laksanakan adalah sebagai berikut:

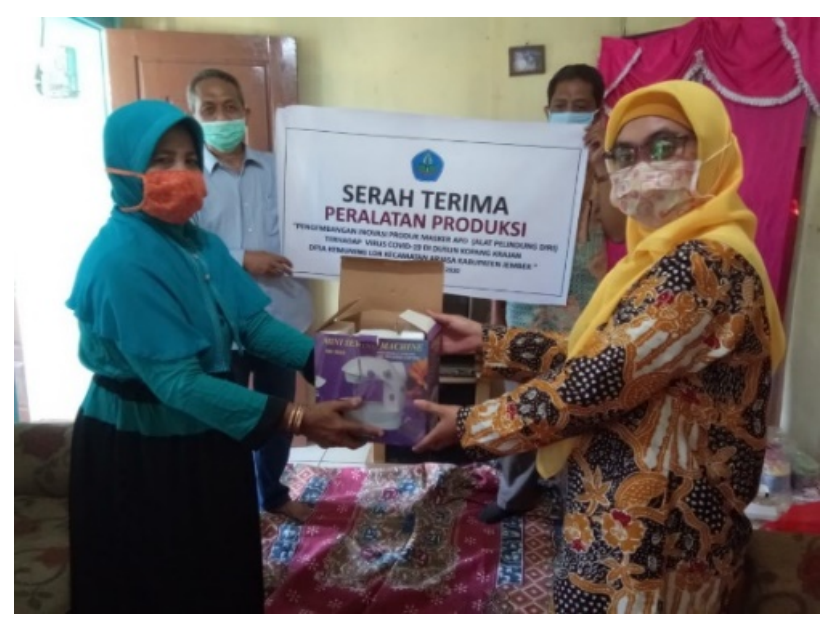

Gambar 1. Serah Terima Mesin Jahit Portable

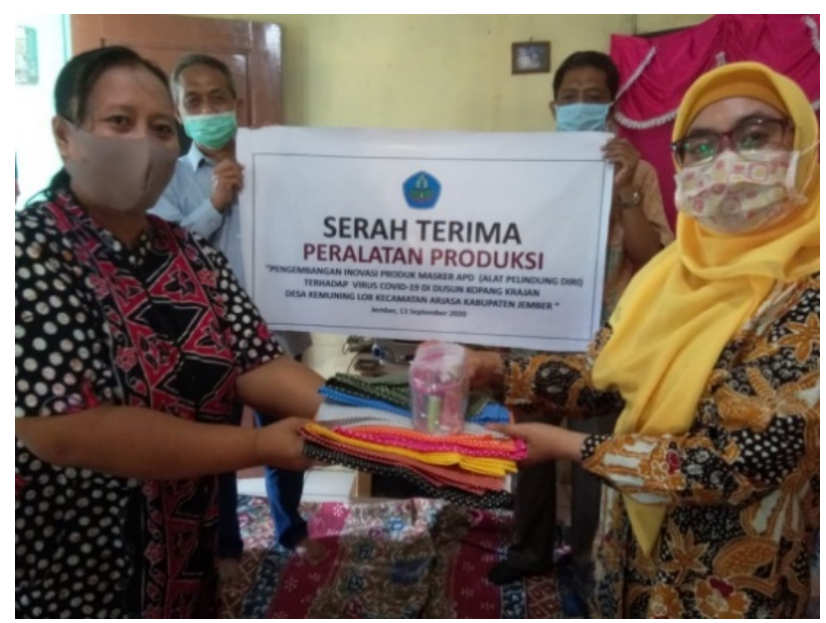

Gambar 2. Serah Terima Sewing Kit, Peralatan Menjahit, dan Bahan Kain Katun Jepang

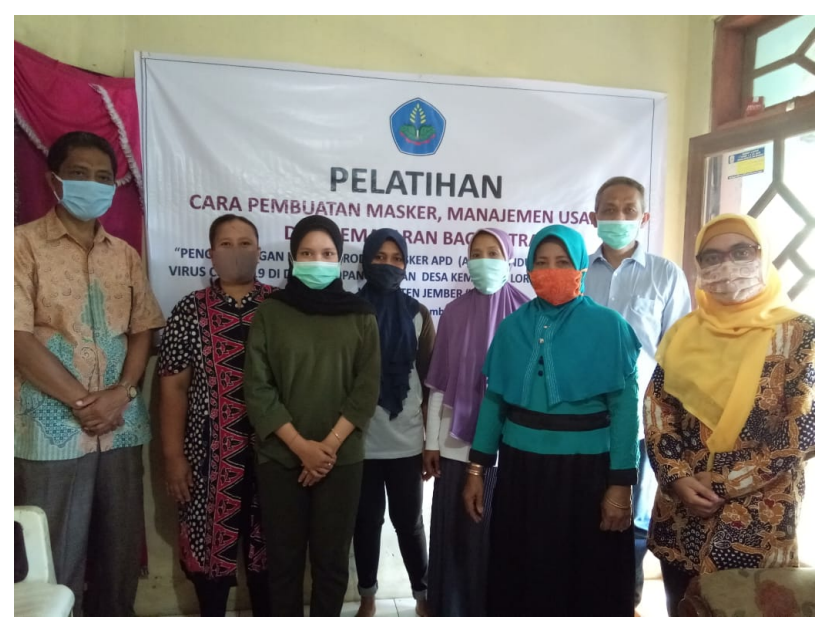

Gambar 3. Pelatihan Cara Pembuatan Masker, Manajemen Usaha, Manajemen Pemasaran

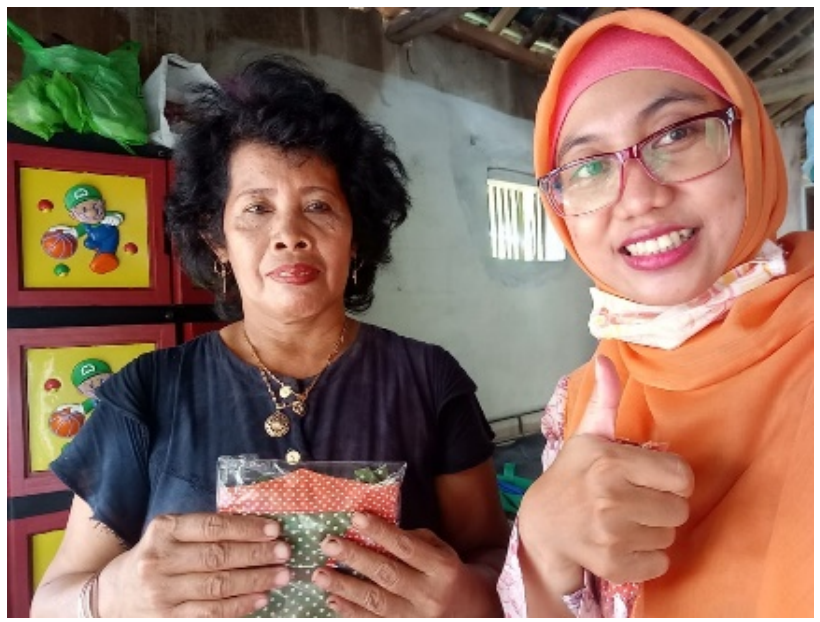

Gambar 4. Kegiatan Monitoring dan Evaluasi pada Mitra

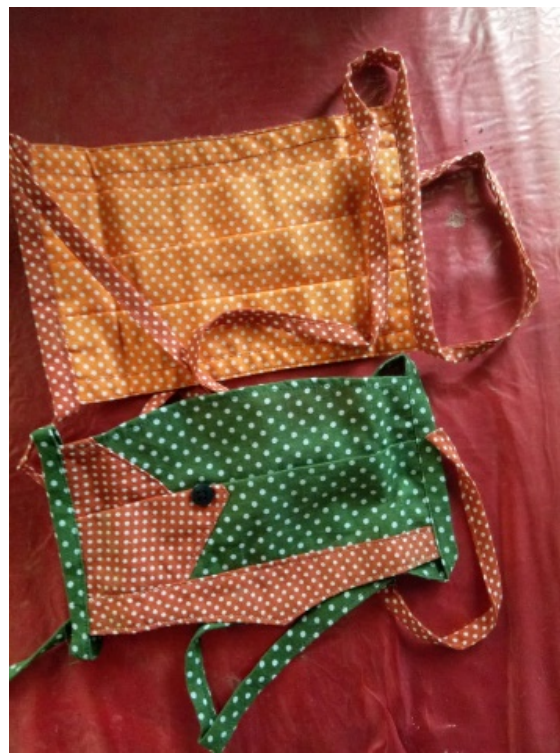

Gambar 5. Masker Kain Hasil Produksi Mitra 


\section{Kesimpulan}

\subsection{Kesimpulan}

a. Kegiatan pengabdian pada mitra $\mathrm{Bu}$ Busani yang meliputi : pemberian materi pelatihan dan pemberian bantuan berupa alat dan mesin produksi jahit berlangsung dengan lancar dan sukses. Hal ini tampak dari antusiasme mitra dan peserta saat diberikan materi pelatihan dan diberikan bantuan alat dan mesin produksi menjahit.

b. Kegiatan pelatihan berupa pemberian materi bidang manajemen usaha dan manajemen pemasaran diharapkan dapat memperbaiki kemampuan manajerial usaha mitra, dapat memperluas daerah pemasaran serta menemukan strategi tepat dalam memasarkan produk maskernya kepada konsumen. Melalui pelatihan desain masker diharapkan mitra akan dapat membuat masker yang menarik sesuai dengan keinginan konsumen.

c. Pemberian bantuan alat dan mesin produksi kepada mitra diharapkan akan dapat meningkatkan efektivitas dan efisiensi proses produksi usaha jahit masker.

\subsection{Saran}

Program Pengabdian Kepada Masyarakat diharapkan akan dapat berlangsung secara berkelanjutan dalam bidang- bidang lainnya agar dapat memberikan manfaat bagi peningkatan kesejahteraan masyarakat pada wilayah tersebut.

\section{Ucapan Terima Kasih}

Kegiatan Pengabdian kepada Masyarakat ini dibiayai oleh DIPA Politeknik Negeri Jember No. SP. DIPA-023.18.2.677607/2020 Tanggal 27 Desember 2019, Sesuai Dengan Surat Perjanjian Pelaksanaan Program Pengabdian kepada Masyarakat Pendanaan Pelaksanaan Program Pengabdian Masyarakat Sumber Dana PNBP POLIJE Tahun Anggaran 2020 Nomor : 656/PL17.4/PM/2020, Tanggal 08 Juni 2020.

\section{Daftar Pustaka}

[1] Direktorat Jenderal Pelayanan Kesehatan Kementerian Kesehatan Republik Indonesia. 2020. Petunjuk Teknis Penggunaan APD dalam Menghadapi Wabah Covid-19. [Online]. Available: www.ibi.or.id.
[2] Harrianto, Ridwan. 2009. Buku Ajar Kesehatan Kerja. Jakarta: EGC.

[3] Aninda Istika Miftasari. 2012. Hubungan Antara Kadar Debu dan Pemakaian Masker dengan Kapasitas Vital Paru pada Pekerja Bagian Pengamplasan UD. Putra Kusuma Jati di Kelurahan Jepon Kabupaten Blora Tahun 2011. Skripsi. Sarjana Kesehatan Masyarakat Fakultas Ilmu Keolahragaan Universitas Negeri Semarang. Diakses pada 26 April 2020, www.lib.unnes.ac.id/18262/1/6450406556.pdf

[4] Badan Pusat Statistik Kabupaten Jember, Jember Regency in Figures 2020. BPS Kabupaten Jember, 2020.

[5] Moh. Ali Mahrus. Berdayakan Penjahit Lokal, Bupati Jember Siapkan 2 Juta Masker. [Online]. Available: https://jatimtimes.com/baca/212146/20200404/1911 00/berdayakan-penjahit-lokal-bupati-jembersiapkan-2-juta-masker 